Tingkat Standarisasi Tenaga Perpustakaan ...(Sungadi)

\title{
TINGKAT STANDARISASI TENAGA PERPUSTAKAAN : Studi Kasus pada Perpustakaan Universitas Islam Indonesia Yogyakarta
}

\author{
Sungadi \\ Pustakawan Universitas Islam Indonesia \\ sungadi@uii.ac.id
}

\begin{abstract}
Penelitian ini bermaksud untuk membandingkan jumlah tenaga perpustakaan (pustakawan, tenaga teknis, dan tenaga administrasi) pada Perpustakaan Universitas Islam Indonesia (UII) dengan standar dan peraturan yang berlaku saat ini. Metode penelitian dengan pendekatan deskriptif kuantitatif dan teknik pengumpulan data melalui studi dokumen dengan cara mencermati UU Nomor 43 tahun 2007, SNI 7330: 2009, dan draft SNP 010: 2011 bidang Perpustakaan Perguruan Tinggi dengan kondisi nyata di Perpustakaan UII. Perpustakaan UII saat ini dikelola oleh 1 orang pustakawan madya, 2 orang pustakawan muda, dan 3 orang pustakawan pertama. Pustakawan penyelia 10 orang, pustakawan pelaksana lanjutan 10 orang, dan pustakawan pelaksana sebanyak 6 orang. Perpustakaan UII saat ini dikelola oleh 32 orang. Selain tenaga fungsional, perpustakaan UII juga didukung oleh tenaga administrasi sebanyak 1 orang kepala perpustakaan dan 11 orang staf administrasi. Hasil Penelitian menunjukkan bahwa: Pustakawan murni: 6 orang (13.95\%), Tenaga Teknis Perpustakaan merangkap Pustakawan: 25 orang (58.16\%), Tenaga Administrasi Perpustakaan : 12 orang (27.91\%). Perbandingan pustakawan dengan tenaga teknis perpustakaan dan tenaga administrasi menunjukkan 1:4:2 (6:25:12). Hal ini dapat diinterpretasikan bahwa tenaga perpustakaan UII masih didominasi tenaga teknis dan tenaga administrasi. Perpustakaan UII dengan jumlah pemustaka sebesar 17.000, idealnya mempunyai pustakawan murni sebanyak 13 orang dan kesesuaian baru mencapai 50\%. Rasio jumlah Pustakawan UII dengan jumlah Pemustaka di Perpustakaan UII menunjukkan 1:2.833, standar yang berlaku 1:1.250. Hal ini baru mencapai 44\%. Kepala Perpustakaan UII saat ini belum memenuhi standar yang diperlukan.
\end{abstract}

Kata Kunci : Pustakawan, Tenaga Perpustakaan, dan Perpustakaan

\section{Pendahuluan}

Salah satu pasal dalam Undang-undang Nomor 43 tahun 2007 tentang Perpustakaan, khususnya pasal 24 menyatakan bahwa setiap perguruan tinggi menyelenggarakan perpustakaan dengan memperhatikan Standar Nasional Pendidikan. Pada SNP 010: 2011 telah diatur bahwa Standar Nasional Perpustakaan terdiri atas: standar koleksi perpustakaan, standar sarana dan prasarana, standar pelayanan perpustakaan, standar tenaga perpustakaan, standar penyelenggaraan dan standar pengelolaan, serta standar teknologi informasi. Sementara itu menurut Lynch (1982) dalam Sulistyo-Basuki (2013), elemen yang paling umum digunakan untuk menghasilkan standar Perpustakaan Perguruan Tinggi berjumlah enam, yaitu: besaran koleksi buku, besaran dan komposisi staf (khususnya pustakawan professional), persentase anggaran perpustakaan dari anggaran total perguruan tinggi, kapasitas tempat duduk di perpustakaan, jasa perpustakaan, dan administrasi perpustakaan.

Dari uraian tersebut dapat diambil sebuah kesimpulanbahwastandaryang harus dimilikibagi Perpustakaan Perguruan Tinggi (PPT) adalah antara lain perlu adanya: koleksi perpustakaan, sarana prasarana, standar pelayanan, standar tenaga perpustakaan, standar penyelenggaraan perpustakaan dan pengelolaan, persentase anggaran perpustakaan, jasa layanan, dan kapasitas tempat duduk, serta standar teknologi informasi.

Dalam tulisan ini, penulis hanya akan mengkritisi dan menfokuskan pada salah satu 
standar yang harus dimiliki PPT yaitu yang berkaitan dengan sumber daya manusia (tenaga perpustakaan). Penulis mengambil obyek kajian di Perpustakaan Universitas Islam Indonesia (UII) Yogyakarta. UII merupakan sebuah perguruan tinggi swasta tertua di Indonesia yang lahir pada tanggal 27 Rajab 1364 atau bertepatan pada 8 Juli 1945. Ull merupakan salah satu PTS yang saat ini telah memberlakukan tenaga perpustakaan sebagai tenaga fungsional. Perpustakaan UII saat ini dikelola oleh 1 orang pustakawan madya, 2 orang pustakawan muda, dan 3 orang pustakawan pertama. Sementara itu pustakawan penyelia sebanyak 10 orang, pustakawan pelaksana lanjutan berjumlah 10 orang, dan pustakawan pelaksana sebanyak 6 orang. Jumlah total pustakawan UII saat ini adalah 32 orang. Selain dari tenaga fungsional, perpustakaan UII juga didukung oleh tenaga administrasi sebesar 11 orang staf administrasi. Tenaga perpustakaan UII diakui sebagai tenaga fungsional sejak tahun 1993, dengan mengacu pada SK MENPAN No. 18 Tahun 1988 dengan pemberlakuan impasing.

Menurut data Kopertis Wilayah V Daerah Istimewa Yogyakarta (DIY) saat ini di Kopertis Wilayah $\mathrm{V}$ terdapat 112 perguruan tinggi yang aktif, sedangkan 4 perguruan tinggi tidak aktif. Dari 116 PTS di DIY tersebut, yang sudah memberlakukan tenaga perpustakaan sebagai pegawai fungsional secara penuh baru 2 (dua) PTS yaitu UII dan Universitas Atma Jaya.

\section{Perumusan Masalah}

Berdasarkan pada uraian di atas, masalah yang diteliti dalam penelitian ini adalah mengenai keberadaan tenaga perpustakaan yang terdiri dari pustakawan, tenaga teknis dan tenaga administrasi di Perpustakaan UII. Penelitian ini akan melihat lebih jauh keberadaan tenaga perpustakaan di Perpustakaan Universitas Islam Indonesia Yogyakarta, apakah sudah sesuai dengan standar yang berlaku di Indonesia?

\section{Tujuan Penelitian}

Tujuan dari penelitian ini adalah untuk mengetahui tingkat standarisasi tenaga perpustakaan (pustakawan, tenaga teknis, dan tenaga administrasi) pada Perpustakaan Universitas Islam Indonesia Yogyakarta.

\section{Manfaat Penelitian}

Penelitian ini diharapkan dapat memberikan kontribusi bagi UII dalam rangka meningkatkan kualitas dan kuantitas tenaga perpustakaan (pustakawan, tenaga teknis, dan tenaga administrasi) bagi pemegang kebijakan di UII.

\section{Studi Pustaka}

\section{Pustakawan}

Undang-undang Nomor 43 tahun 2007 tentang Perpustakaan Pasal 1 ayat 8 menjelaskan bahwa Pustakawan adalah seseorang yang memiliki kompetensi yang diperoleh melalui pendidikan dan/atau pelatihan kepustakawanan serta mempunyai tugas dan tanggung jawab untuk melaksanakan pengelolaan dan pelayanan perpustakaan. Sementara itu SNI 7330: 2009 pada angka 2.20 menjelaskan bahwa pustakawan perguruan tinggi adalah pegawai yang berpendidikan serendahrendahnya sarjana di bidang ilmu perpustakaan dan informasi atau yang disetarakan, dan diberi tugas, tanggung jawab, wewenang, dan hak secara penuh oleh pejabat yang berwenang untuk melakukan kegiatan kepustakawanan pada unit-unit perpustakaan. Lebih lanjut menurut SNP 010: 2010 pada angka 2.13 menyebutkan pustakawan perguruan tinggi adalah seseorang yang memiliki kompetensi yang diperoleh melalui pendidikan dan/atau pelatihan kepustakawanan serta mempunyai tugas dan tanggung jawab untuk melaksanakan pengelolaan dan pelayanan perpustakaan. Masih dalam SNP 010: 2010 pada angka 2.13 pustakawan perguruan tinggi adalah berpendidikan serendah-rendahnya sarjana di bidang ilmu perpustakaan dan informasi, dan diberi tugas, tanggung jawab, wewenang, dan hak secara penuh oleh pejabat yang berwenang untuk melakukan kegiatan kepustakawanan pada unit-unit perpustakaan perguruan tinggi. Sedangkan menurut Peraturan UII Nomor 15/ PU/REK/IX/2010 tentang Jabatan Fungsional, Pangkat dan Angka Kredit Pustakawan UII pasal 1 ayat 7 menyatakan bahwa pustakawan adalah tenaga kependidikan tetap UII atau Pegawai Negeri Sipil yang dipekerjakan di lingkungan UII yang diberi wewenang dan tanggung jawab untuk melakukan kegiatan kepustakawanan. 
Dari keempat acuan tersebut terdapat kesamaan, bahwa pustakawan tidak harus berstatus pegawai negeri sipil (PNS) akan tetapi pegawai swasta pun dapat menjadi pustakawan dengan prinsip pegawai tersebut memenuhi syarat-syarat yang diperlukan bagi seorang pustakawan. Persyaratan yang diperlukan adalah yang bersangkutan harus memiliki kompetensi melalui pendidikan di bidang perpustakaan dan informasi, mempunyai tugas dan tanggung jawab dalam melaksanakan seluruh kegiatan perpustakaan, serta mampu mengelola Daftar Usul Penetapan Angka Kredit (DUPAK) dalam kurun waktu yang telah ditentukan. Status sebagai pejabat fungsional pustakawan belumlah lengkap ketika seorang pustakawantidakmemiliki memampuan mengumpulkan dan mengelola Angka Kredit sehingga berujud menjadi DUPAK. Terdapat perbedaan pengertian yang tertuang pada Peraturan Kepala Perpustakaan Nasional Republik Indonesia Nomor 2 Tahun 2008 tentang Petunjuk Teknis Jabatan Fungsional Pustakawan dan Angka Kreditnya Bab II angka 2, dimana dalam peraturan ini menjelaskan bahwa pejabat fungsional Pustakawan adalah seseorang yang berstatus sebagai Pegawai Negeri Sipil. Menurut hemat penulis peraturan KaPerpusnas RI tersebut berseberangan dengan UU Nomor 43 tahun 2007.

Seorang pustakawan adalah spesialis informasi yang terlatih yang memegang gelar sarjana IImu Perpustakaan dan Master IImu Perpustakaan dan Informasi (MLIS). Sebagai ahli informasi, pustakawan memiiliki peran mencari dan menemukan informasi, menghimpun dan mengatur informasi, serta menerapkan sistem temu kembali informasi sehingga informasi mudah diakses dari lokasi yang jauh tanpa terkendala oleh ruang dan waktu (http://www.lib. sk.ca/Librarian, akses tanggal 21 Juni 2014 pk 09:34).

Pustakawan dilatih untuk mengumpulkan dan menemukan semua jenis informasi buku, surat kabar, majalah, database, website, CD, video, publikasi pemerintah dan jenis informasi lainnya data yang tersedia untuk umum. Mereka juga dilatih untuk mengembangkan sistem untuk mengatur dan mengelola informasi ini sehingga dapat dengan mudah diambil. Pustakawan merancang dan memberikan layanan informasi untuk kelompok klien mereka juga.
Pustakawan memiliki berbagai peran yang tersedia bagi mereka, tergantung pada jenis perpustakaan atau pengaturan mereka bekerja masuk dalam pengaturan yang lebih tradisional, seperti perpustakaan umum, pustakawan dapat mengkhususkan dalam pekerjaan bidang referensi, pengembangan koleksi, katalog, koleksi anak, layanan pemuda dan sistem komputer perpustakaan, dan lainnya. Dalam sebuah perpustakaan khusus yang kecil, setiap saat pustakawan dapat bekerja dengan sistem koleksi, referensi, katalog, instruksi, atau komputer. Dalam pengaturan pekerjaan alternatif, di luar perpustakaan tradisional, pustakawan semakin memainkan peran sebagai pengembang website, petugas informasi perusahaan, dan broker informasi.

Pustakawan adalah profesi tertua informasi. Sekarang, di era informasi, bidang mereka berkembang pesat. Sebagai perubahan lapangan dan berevolusi, mereka yang mempelajari ilmu perpustakaan dan informasi akan memiliki banyak peluang di sektor informasi dan teknologi, serta berbagai jenis perpustakaan.

Di beberapa tempat karir pustakawan bukanlah tanpa nama, tak berwajah satu. Berikut adalah mungkin untuk membuat nama untuk diri sendiri dan untuk mengetahui rekan kerja, bahkan jika mereka bekerja di perpustakaan atau cabang lainnya. Jumlah perpustakaan dan pekerjaan pustakawan diproyeksikan meningkat pada tahun 2005.

\section{Pendidikan}

Kebanyakan orang yang ingin masa depan mereka berada di perpustakaan atau arsip mendapatkan gelar Master dalam IImu Perpustakaan. Biro Statistik Tenaga Kerja menyatakan,"TingkatMagisterllmuPerpustakaan menyediakan persiapan umum untuk pekerjaan perpustakaan, tetapi beberapa individu mengkhususkan diri dalam bidang tertentu, seperti referensi, layanan teknis, atau layanan anak-anak. Sebuah lembaga pendidikan program doctoral (Ph.D.) pada prodi IImu Perpustakaan dan IImu Informasi sangat menguntungkan untuk posisi mengajar pada sebuah perguruan tinggi atau pekerjaan administratif di sebuah perguruan tinggi atau perpustakaan universitas atau sistem perpustakaan umum yang besar" 
(United States Department of Labor). Pendidikan merupakan faktor kunci dalam keterampilan yang dibutuhkan untuk menjadi pustakawan. Keterampilan yang diajarkan di kelas pada saat lembaga yang memberikan gelar Magiter IImu Perpustakaan terus akan dicari oleh mereka yang mempekerjakan karyawan perpustakaan pada posisi analis informasi. Membuat website, metode pembelajaran mencari dan mengevaluasi, dan belajar metode yang tepat dalam sebuah wawancara referensi dan hanya dari beberapa mata pelajaran untuk dapat meraih gelar Magister IImu Perpustakaan dan Informasi. Kebanyakan posisi tingkat atas yang terlihat tersedia untuk beberapa pendidikan tinggi di Perpustakaan dan Teknologi Informasi.

\section{Pengetahuan Teknis dan Pelatihan}

Di dunia Web 2.0 saat ini, pustakawan perlu memiliki kemampuan dalam mengelola informasi dalam format digital. Untuk menjadi mahir dalam teknologi dan komputer sangat penting untuk menjadi seorang pustakawan yang sukses. Dengan komputer, pustakawan harus mampu menavigasi pada mesin dan akses informasi dari internet serta sumbersumber digital lainnya. "Sementara pustakawan tidak harus menjadi teknisi, apakah mereka memerlukan keterampilan komputer? Penny Beile dan analisis isi Megan Adams menyatakan bahwa posisi perpustakaan 'sebagai sumber informasi', di perpustakaan akademik/perguruan tinggi yang menyajikan informasinya melalui media elektronik, keterampilan komputer merupakan hal penting yang dicari oleh berbagai perpustakaan" (Mathews, 2009). Mampu membantu pengguna secara elektronik adalah bagian penting dari kegiatan pustakawan umum dan akademik dalam mengemban tugas seharihari. Pengetahuan dan pemahaman tentang komputer yang tinggi pada daftar keterampilan yang dibutuhkan ketika pelatihan berada di perpustakaan.

Seiring dengan kemampuan masyarakat mengakses informasi dari internet, merupakan hasil kemampuan perpustakaan dalam melakukan promosinya sehingga dapat terhubung dengan pengguna juga. Banyak perpustakaan saat ini menggunakan seperti Web 2.0 seperti Twitter, Facebook, dan
Myspace untuk terhubung dengan pelanggan mereka dan memperbarui mereka pada acaraacara khusus, pengumuman, dan program perpustakaan. Memiliki account di situs tersebut juga memungkinkan perpustakaan untuk berkomunikasi dengan pengguna. Komunikasi dapat diselenggarakan dalam bentuk pertanyaan dan dapat dijawab, melalui jaringan internet, sehingga keduanya lebih cepat dan lebih mudah untuk berkomunikasi bagi kedua belah pihak.

\section{Pustakawan saat ini juga sedang terpanggil} untuk membuat website, wiki, dan pathfinders dalam rangka untuk lebih mempromosikan perpustakaan dan meningkatkan akses terhadap informasi. Keterampilan teknologi ini sangat dihargai dan dicari ketika posisi perpustakaan terbuka untuk aplikasi. "Jelas perolehan keterampilan yang dibutuhkan untuk mengakses, menyimpan, mengelola, dan menyebarkan media (seperti buku elektronik dan jurnal, bahan cetak, bahan audiovisual, dan situs Web) di perpustakaan adalah contoh lain dari sejarah panjang pustakawan beradaptasi dengan mengadopsi teknologi baru. Selanjutnya, kami percaya bahwa pustakawan dituntut tidak hanya untuk mengelola media itu sendiri, tetapi juga untuk memperoleh, mengembangkan, menyebarkan, menggunakan, dan memelihara seperangkat teknologi informasi dan sistem yang mendukung mereka" (Mathews, 2009).

\section{Organisasi dan Evaluasi Keterampilan}

Seringkali, pustakawan diminta untuk melakukan banyak tugas, mulai dari membantu dalam mencari informasi, menerima pesanan bahan pustaka, mempersiapkan presentasi tentang perpustakaan untuk masyarakat atau dewan direksi. "Sebuah Referensi Pustakawan harus responsif terhadap kebutuhan pengguna, berpikir kritis dan diatur serta mengatur atau mengkoordinasikan proyek-proyek dan layanan bagi pengguna" (LIS Wiki). Tanpa keterampilan organisasi, pustakawan akan goyah di bawah jumlah, dan jenis pekerjaan yang mereka miliki. Mereka akan kehilangan kesempatan dalam membantu pengguna, dan diri mereka sendiri.

Selarasdengankemampuanuntukmultitask dan mengatur dalam kerja perpustakaan secara keseluruhan, datang keterampilan organisasi dan evaluasi yang datang dengan bekerja 
satu-satu dengan pengguna berusaha untuk menjawab pertanyaan tertentu. Pustakawan harus dapat memisahkan informasi yang baik dan buruk dari database atau pencarian online untuk memberikan jawaban kepada pengguna perpustakaan yang terbaik. Hal ini sering dirasakan sulit hari ini di dunia, di mana situs yang populer pada mesin pencari seperti Google dan Yahoo! tidak dapat memberikan informasi yang diperlukan atau yang benar dan sesuai dengan kebutuhan. Hal ini tidak hanya berlaku untuk memberikan informasi kepada pengguna, tetapi juga untuk orang-orang yang lebih tinggi jabatannya di sebuah perpustakaan. Mary Ellen Bates menulis dalam artikelnya "The MLS baru dicetak: Apa yang Kita Harus Tahu Hari ini," "Kita perlu lulusan yang dapat mengevaluasi sumber informasi dan memutuskan apakah itu dilakukan atau tidak memiliki nilai untuk situasi tertentu. Sebagai contoh, kita membutuhkan orang yang dapat pergi melalui hasil pencarian, mengeluarkan bahan yang paling berguna, mengaturnya, menulis ringkasan eksekutif, dan memoles produk akhir sehingga tampak seperti laporan dan bukan data sampah. "(Bates, 1998).

\section{Manajemen Bisnis}

Meskipun perpustakaan bukan merupakan sebuah lembaga bisnis, akan tetapi mereka menghadapi kesulitan dan masalah yang sama ketika datang untuk mengelola bisnis. Seringkali, pustakawan berada di bawah pengawasan dari atasan atau pengusaha untuk memastikan bahwa perpustakaan, harus mampu membantu bagi pelanggan. Agar perpustakaan dapat meraih kesuksesan dalam melayani pemustaka, pustakawan harus mampu memasarkan sesuai dengan misi perpustakaan. "Berpikir seperti seorang pengusaha. Terlepas dari apa jenis perpustakaan atau layanan informasi kita dalam bekerja, kita harus memasarkan layanan secara terus-menerus. Sebagai salah satu pustakawan mengatakan, "Ide-ide terbaik tidak pernah berhenti; ide-ide promosi terbaik harus diutamakan "(Bates, 1998). Menyediakan pustakawan yang memiliki kemampuan berbisnis memungkinkan perpustakaan untuk tetap eksis dalam menyebarkan berbagai bentuk informasi.

Aspek lain dari manajemen bisnis adalah pemasaran perpustakaan Anda. Hal ini dapat dilakukan dengan menghubungi koran lokal dan mengundang mereka dalam berbagai acara perpustakaan, dengan mengirimkan newsletter kepada pelanggan, dan memberikan hadiah secara khusus bagi pelanggan yang aktif memanfaatkan perpustakaan (librarysuccess. org). Hal lain juga dapat dilakukan dengan memberikan pelatihan teknologi kepada para pustakawan dengan memulai akun Facebook atau Twitter. "Memiliki Twitter feed yang dikelola dengan baik dapat menjadi outlet yang sangat efektif untuk mendapatkan pesan setiap organisasi dari para pelanggannya. Mengingat keunggulan dari penggunaan Twitter oleh basis pelanggan dari kebanyakan organisasi, maka akan membangkitkan partisipasi pelanggan terhadap aktivitas perpustakaan secara serius dalam strategi media perusahaan" (Breeding, 2009). Pelatihan dan kesadaran manajemen dan pemasaran keterampilan akan memungkinkan dalam peningkatan informasi diarahkan pengguna dan anggota masyarakat tentang perpustakaan, tujuan dan layanannya.

\section{Keterampilan Interpersonal}

Meskipun terakhir dalam daftar ini keterampilan yang diperlukan, itu sangat penting bahwa pustakawan dapat berkomunikasi dengan pengguna yang datang mencari informasi, serta pengusaha dan rekan kerja. Berinteraksi dengan pengunjung perpustakaan, kemampuan memberikan layanan referensi adalah kunci untuk interaksi yang sukses antara pustakawan referensi dengan pengguna. Wawancara ini memungkinkan pustakawan untuk mengumpulkan apa yang diinginkan pengguna, dan dalam bentuk apa yang mereka inginkan. Kadang-kadang, hanya ini pertukaran beberapa menit bagi pustakawan harus mencari tahu semua yang mereka bisa tentang bagaimana dapat membantu pengguna. Menurut Mary Ellen Bates, "profesional informasi tidak sekedar menerima pesanan seperti halnya pesan menu di sebuah restoran makanan cepat saji ("Apakah Anda ingin kentang goreng dengan berbagai kombinasi itu, Pak?"). Sebaliknya, kami bertindak sebagai konsultan yang bekerja dengan klien kami, menganalisis kebutuhan informasi mereka, mengevaluasi sumber daya yang tersedia serta anggaran dan waktu yang 
perpustakaandengan pendidikanminimaldiploma tiga serta memperoleh pelatihan kepustakawan dari lembaga pendidikan dan pelatihan yang terakreditasi (SNP 010: 2011, 6.3). Selanjutnya penjelasan pada UU Nomor 43 tahun 2007 Pasal 29 (1) Tenaga perpustakaan terdiri atas pustakawan dan tenaga teknis perpustakaan. (2) Pustakawan sebagaimana dimaksud pada ayat (1) harus memenuhi kualifikasi sesuai dengan standar nasional perpustakaan. (3) Tugas tenaga teknis perpustakaan sebagaimana dimaksud pada ayat (1) dapat dirangkap oleh pustakawan sesuai dengan kondisi perpustakaan yang bersangkutan.

Lebih lanjut pada SNP 010: 2011 disebutkan bahwa tenaga perpustakaan perguruan tinggi terdiri dari pustakawan, tenaga teknis perpustakaan, tenaga administrasi, tenaga teknologi informasi dan kepala perpustakaan. Jumlah tenaga Perpustakaan dikelola oleh tenaga perpustakaan sekurang-kurangnya 2 orang pustakawan. Untuk 500 mahasiswa pertama: 1 orang pustakawan dan 1 orang staf. Untuk setiap tambahan 2000 mahasiswa, ditambahkan 1 orang pustakawan. Perpustakaan memberikan kesempatan untuk pengembangan sumber daya manusianya melalui pendidikan formal dan nonformal kepustakawanan.

Menurut SNI 7330: 2009 pada angka 8.2 memberikan penjelasan bahwa jumlah sumber daya manusia yang diperlukan dihitung berdasarkan perbandingan satu pustakawan, dua tenaga teknis perpustakaan dan satu tenaga administrasi. Di dalam SNI 7330: 2009 ini tidak ada penjelasan jumlah rasio pustakawan dengan jumlah pemustaka, sehingga agak sukar untuk mengukur kebutuhan jumlah pustakawan yang harus disediakan bagi perpustakaan perguruan tinggi. Sedangkan penjelasan yang terdapat di SNP 010: 2011 sudah dengan jelas disebutkan bahwa jumlah pustakawan yang diperlukan adalah 1 pustakawan berbanding 500 pemustaka, dan hitungan lebih lanjut setiap 2000 mahasiswa ditambah satu pustakawan. Atau setara dengan 1:1250, artinya rasio kebutuhan pustakawan adalah 1 berdanding 1.250 pemustaka.

\section{Metodologi Penelitian}

\section{Tempat dan Waktu Penelitian}

Penelitian dilakukan di Universitas Islam Indonesia Yogyakarta. Pemilihan lokasi penelitian ini dengan mempertimbangkan beberapa aspek antara lain: masalah yang diteliti berada di Universitas Islam Indonesia, Peneliti bekerja di Universitas Islam Indonesia, dan dalam rangka efisiensi biaya, waktu dan tenaga. Penelitian dilakukan antara bulan April-Agustus 2014.

\section{Populasi, Sampel dan Model Penentuan Sampel}

Populasi adalah keseluruhan individu yang merupakan sasaran sesungguhnya dalam penelitian. Menurut Kountur (2003) populasi adalah suatu kumpulan menyeluruh dari suatu obyek yang merupakan perhatian peneliti. Obyek penelitian dapat berupa makhluk hidup, benda-benda, sistem, prosedur, fenomena, dan lain-lain.

Dalam penelitian ini yang dimaksud dengan populasi adalah tenaga perpustakaan (pustakawan, tenaga teknis, dan tenaga administrasi) Perpustakaan UII (pustakawan) yang digunakan sebagai objek penelitian. Peneliti mengambil semua pustakawan UII (sebanyak 32 orang) untuk dipilih sebagai objek penelitian, sehingga metode yang digunakan adalah metode total sampling.

\section{Teknik Pengumpulan Data}

Teknik pengumpulan data dilakukan melalui studi dokumen, yaitu dengan cara mencermati UU Nomor 43 tahun 2007, SNI 7330:2009, dan draft SNP 010: 2011. Dari hasil studi dokumen kemudian dilakukan studi lapangan dengan melihat kondisi riil SDM di Direktorat Perpustakaan dan Perpustakaan Fakultas di lingkungan UII. Dari kedua hasil studi tersebut selanjutnya dilakukan analisis data untuk mengetahui apakah SDM di Perpustakaan UII telah sesuai dengan standar atau belum.

\section{Teknik Analisis Data}

Sesuai dengan tujuan penelitian, data yang diperoleh dari studi dokumen akan dianalisis secara deskriptif kuantitatif yaitu dengan memaparkan data-data yang ada sedetail 
mungkin dengan memvisualiasikan ke dalam sebuah tabel, kemudian dilakukan pembahasan secara keseluruhan sehingga dapat diketahui dan dianalisis, kemudian dapat ditarik suatu kesimpulan dengan melalui beberapa tahapan antara lain:

\section{a. Scoring}

Merupakan kegiatan memberi score atau nilai sesuai ukuran-ukuran yang telah ditentukan dalam jawaban kuesioner. Pemberian score dilakukan dengan cara menghitung jumlah pustakawan UII dengan mengkomparasikan pada UU dan standar yang ada untuk selanjutnya akan dilakukan analisis data.

b. Tabulasi

Tabulasi adalah proses memasukkan data pada tabel-tabel tertentu dan mengatur angka-angka serta menghitungnya, sehingga menjadi tabel frekuensi. Dalam hal ini tabel data berisikan jenjang pendidikan, bidang ilmu, sertifikat kompetensi, status jabatan fungsional, jumlah, persentase, Masuk Kualifikasi SNI 7330: 2009, dan Masuk Kualifikasi SNP 010: 2011. Rumus persentase dari frekuensi dalam penelitian ini menggunakan:

$$
\begin{aligned}
& f \quad \text { Keterangan: } \\
& N=-\times 100 \% \quad \begin{array}{l}
N=\text { Nilai Hasil } \\
\mathrm{f}=\text { Frekuensi }
\end{array} \\
& n \quad f=\text { Frekuensi } \\
& \mathrm{n}=\text { Jumlah }
\end{aligned}
$$

Gambar 1: Rumus persentase, (Singarimbun, 1994)

Untuk selanjutnya dalam proses analisis data akan digunakan statistik untuk menyederhanakan data penelitian dengan mencari data terendah dan data tertinggi, kemudian dicari rentangnya, maka lebar dan jumlah interval yang tepat dapat ditetapkan (Riduwan, 2003).

\section{Pengukuran Variabel}

Standar Sumber Daya Manusia (SDM) Perpustakaan Perguruan Perguruan Tinggi: Studi Kasus pada Universitas Islam Indonesia

\begin{tabular}{|c|c|}
\hline VARIABEL & INDIKATOR \\
\hline $\begin{array}{l}\text { 1. Kualifikasi } \\
\text { Te n a g a } \\
\text { Perpustakaan } \\
\text { UIl }\end{array}$ & $\begin{array}{ll}\text { 1. } & \text { S3 (Doktor) } \\
\text { 2. } & \text { S2 (Magister) } \\
\text { 3. } & \text { S1 (Sarjana) } \\
\text { 4. } & \text { D3 (Diploma) } \\
\text { 5. } & \text { D2 (Diploma) } \\
\text { 6. } & \text { SLTA }\end{array}$ \\
\hline $\begin{array}{l}\text { 2. Rasio Tenaga } \\
\text { Perpustakaan } \\
\text { Ull }\end{array}$ & $\begin{array}{l}\text { 1. Jumlah Pustakawan } \\
\text { 2. Jumlah Tenaga Teknis } \\
\text { Perpustakaan } \\
\text { 3. Jumlah Tenaga Administrasi } \\
\text { 4. Jumlah Pemustaka }\end{array}$ \\
\hline $\begin{array}{l}\text { 3. Kualifikasi } \\
\text { K e p a I a } \\
\text { Perpustakaan } \\
\text { UIl }\end{array}$ & $\begin{array}{l}\text { 1. Latar Belakang Pendidikan } \\
\text { 2. Status Pejabat Fungsioal } \\
\text { Pustakawan }\end{array}$ \\
\hline
\end{tabular}
Yogyakarta, dapat diukur dengan melalui indikator dalam tabel 1 sebagai berikut:
Tabel 1 Pengukuran Variabel 


\section{Hasil Dan Pembahasan}

Penelitian yang dilakukan memperoleh hasil sebagai berikut:

\section{Perbandingan antara Data SDM yang dimiliki Perpustakaan UII dengan SNP 2011}

Tabel 2 Kondisi Riil SDM Perpustakaan UII dengan SNP 2011

\begin{tabular}{|c|c|c|c|c|}
\hline No & Kualifikasi & Data SDM UII & $\begin{array}{l}\text { Standar Yang } \\
\text { Seharusnya }\end{array}$ & Keterangan \\
\hline 1 & Pendidikan & $\begin{array}{l}\text { 1. S3 } \\
\text { 2. S2 } \\
\text { 3. S1 } \\
\text { 4. D3 } \\
\text { 5. D2 } \\
\text { 6. SLTA }\end{array}$ & $\begin{array}{l}\text { 1. S3 } \\
\text { 2. S2 } \\
\text { 3. S1 } \\
\text { 4. D3 } \\
\text { 5. D2 } \\
\text { 6. SLTA }\end{array}$ & Sesuai \\
\hline 2 & $\begin{array}{l}\text { Komposisi Status } \\
\text { Jabatan Fungsional } \\
\text { dan non Fungsional } \\
\text { serta pejabat Kepala } \\
\text { Perpustakaan }\end{array}$ & $\begin{array}{l}\text { 1. Pustakawan } \\
\text { 2. Tenaga Teknis } \\
\text { Perpustakaan } \\
\text { 3. Tenaga } \\
\text { Administrasi } \\
\text { 4.-- } \\
\text { 5. Kepala } \\
\text { Perpustakaan }\end{array}$ & $\begin{array}{l}\text { 1. Pustakawan } \\
\text { 2. Tenaga Teknis } \\
\text { Perpustakaan } \\
\text { 3. Tenaga } \\
\text { Administrasi } \\
\text { 4. Tenaga } \\
\text { Teknologi } \\
\text { Informasi } \\
\text { 5. Kepala } \\
\text { Perpustakaan }\end{array}$ & $\begin{array}{l}\text { Sesuai } \\
\text { Sesuai } \\
\text { Sesuai } \\
\text { Belum } \\
\text { Sesuai }\end{array}$ \\
\hline 3 & $\begin{array}{l}\text { Rasio Pustakawan } \\
\text { dengan Tenaga Teknis } \\
\text { Perpustakaan dan } \\
\text { Tenaga Administrasi }\end{array}$ & $1: 4: 2$ & $1: 2: 1$ & Belum \\
\hline 4 & $\begin{array}{l}\text { Rasio Pustakawan } \\
\text { dengan Pemustaka }\end{array}$ & $1: 2.833$ & $1: 1.250$ & Belum \\
\hline 5 & $\begin{array}{l}\text { Rasio Pustakawan } \\
\text { Merangkap tenaga } \\
\text { Teknis Perpustakaan } \\
\text { dengan Pemustaka }\end{array}$ & $1: 548$ & $1: 1.250$ & Sesuai \\
\hline 6 & $\begin{array}{l}\text { Bidang Pendidikan } \\
\text { Kepala Perpustakaan }\end{array}$ & $\begin{array}{l}\text { S3 Bidang IImu } \\
\text { Teknik }\end{array}$ & $\begin{array}{l}\text { Minimal S2 IImu } \\
\text { Perpustakaan }\end{array}$ & Belum \\
\hline
\end{tabular}

Sumber: Data Olahan

Tabel 2 di atas nampak bahwa ada 11 (sebelas) komponen yang telah sesuai dengan standar dari 15 (lima belas) komponen yang ditetapkan SNP. Sementara 4 (empat) komponen masih belum memenuhi standar SNP, uraian lebih lanjut sebagai berikut: 
Tabel 3 Tingkat Pendidikan Tenaga Perpustakaan UII

\begin{tabular}{|c|c|c|c|c|c|c|c|c|}
\hline No & $\begin{array}{c}\text { Jenjang } \\
\text { Pendidikan }\end{array}$ & Bidang IImu & $\begin{array}{c}\text { Sertifikat } \\
\text { Kompe- } \\
\text { tensi }\end{array}$ & $\begin{array}{c}\text { Status } \\
\text { Jabatan } \\
\text { Fungsional }\end{array}$ & Jumlah & $\begin{array}{c}\text { Persentase } \\
(\%)\end{array}$ & $\begin{array}{l}\text { Kesesuaian } \\
\text { dengan MK } \\
\text { SNI } 7330^{*} \text { ) }\end{array}$ & $\begin{array}{c}\text { Kesesuaian } \\
\text { dengan MK } \\
\text { SNP }{ }^{* *} \text { ) }\end{array}$ \\
\hline 1 & S3 & IImu Teknik & Tidak ada & $\begin{array}{c}\text { Non } \\
\text { Pustakawan }\end{array}$ & 1 & 2.33 & Tidak & Tidak \\
\hline 2 & $\mathrm{~S} 2$ & $\begin{array}{l}\text { IImu } \\
\text { Perpusta- } \\
\text { kaan }\end{array}$ & - & Pustakawan & 3 & 6.98 & $\mathrm{Ya}$ & Ya \\
\hline 3 & $\mathrm{~S} 1$ & $\begin{array}{c}\text { Ilmu } \\
\text { Perpusta- } \\
\text { kaan } \\
\end{array}$ & - & Pustakawan & 3 & 6.98 & $\mathrm{Ya}$ & $\mathrm{Ya}$ \\
\hline 4 & D3 & $\begin{array}{l}\text { Ilmu } \\
\text { Perpusta- } \\
\text { kaan }\end{array}$ & - & Pustakawan & 8 & 18.60 & $\begin{array}{l}\text { Ya dan } \\
\text { Tidak }\end{array}$ & $\begin{array}{l}\text { Ya dan } \\
\text { Tidak }\end{array}$ \\
\hline 5 & D3 & $\begin{array}{l}\text { Ilmu } \\
\text { Perpusta- } \\
\text { kaan }\end{array}$ & - & $\begin{array}{c}\text { Non } \\
\text { Pustakawan }\end{array}$ & 2 & 4.65 & Tidak & Tidak \\
\hline 6 & D3 & $\begin{array}{l}\text { Non } \\
\text { Perpusta- } \\
\text { kaan }\end{array}$ & Ada & Pustakawan & 1 & 2.33 & $\begin{array}{l}\text { Ya dan } \\
\text { Tidak }\end{array}$ & $\begin{array}{l}\text { Ya dan } \\
\text { Tidak }\end{array}$ \\
\hline 7 & D2 & $\begin{array}{c}\text { Ilmu } \\
\text { Perpustakaan }\end{array}$ & - & Pustakawan & 2 & 4.65 & $\mathrm{Ya}$ & Tidak \\
\hline 8 & D2 & $\begin{array}{c}\text { Ilmu } \\
\text { Perpustakaan }\end{array}$ & - & $\begin{array}{c}\text { Non } \\
\text { Pustakawan }\end{array}$ & 1 & 2.33 & Tidak & Tidak \\
\hline 9 & SLTA & - & Ada & Pustakawan & 14 & 32.56 & Tidak & Tidak \\
\hline 10 & SLTA & - & Tidak Ada & $\begin{array}{c}\text { Non } \\
\text { Pustakawan }\end{array}$ & 6 & 13.95 & Tidak & Tidak \\
\hline 11 & SLTP & - & Tidak Ada & $\begin{array}{c}\text { Non } \\
\text { Pustakawan }\end{array}$ & 2 & 4.65 & Tidak & Tidak \\
\hline & \multicolumn{4}{|c|}{ JUMLAH } & 43 & 100 & & \\
\hline
\end{tabular}

Sumber: Kepegawaian UII

*) Memenuhi Kualifikasi pada SNI 7330: 2009; **) Memenuhi Kualifikasi SNP 010:2011

\section{Kualifikasi Tenaga Perpustakaan UII}

Tabel 3 diatas terlihat bahwa dilihat dari jenjang pendidikan pegawai Perpustakaan Universitas Islam Indonesia per 2 Juli 2013 adalah jenjang S3 sebanyak 1 orang (2.33\%), S2 sebanyak 3 orang $(6.98 \%)$ dan S1 sebanyak 3 orang (6.98\%). Sementara itu yang memiliki jenjang Diploma Tiga (D3) sebanyak 11 orang (25.58\%), D2 sebanyak 3 orang (6.98\%), SLTA sebanyak 20 orang $(46.51 \%)$, dan SLTP sebanyak 2 orang (4.65\%). Hal ini menunjukkan bahwa jenjang pendidikan pegawai Perpustakaan UII paling besar adalah pendidikan tingkat SLTA sebesar $46.51 \%$. Urutan selanjutnya secara berturut adalah jenjang pendidikan D3 sebesar $25.58 \%$, jenjang S2, S1 dan D2 masing-masing sebesar $6.98 \%$, SLTP sebesar $4.65 \%$, dan S3 sebesar $2.33 \%$.

Dengan mengacu pada SNP 010: 2011 pada angka 6.3 yang menyebutkan bahwa Kualifikasi tenaga perpustakaan perguruan tinggi adalah pustakawan minimal strata satu di bidang ilmu perpustakaan dan informasi, maka pejabat Fungsional Pustakawan UII yang memiliki kualifikasi sesuai dengan jenjang pendidikan hanya sebanyak 6 orang (13.95\%). Masih menurut SNP 010: 2011 pada angka 6.3 tenaga teknis perpustakaan dengan pendidikan minimal diploma tiga serta memperoleh pelatihan kepustakawan dari lembaga pendidikan dan pelatihan yang terakreditasi, maka yang masuk kualifikasi SNP Perguruan Tinggi di UII hanya sebanyak 9 orang (20.93\%). Sementara menurut SNI 7330: 2009 pada angka 2.22 menjelaskan bahwa tenaga Teknis Perpustakaan Perguruan Tinggi adalah pegawai yang berpendidikan serendah-rendahnya diploma dua di bidang ilmu perpustakaan dan informasi, maka yang masuk kualifikasi SNI Perpustakaan Perguruan Tinggi di UII hanya sebanyak 11 orang (25.58\%).

Tabel 1 kolom Nomor 4 dan 7 terdapat isian Ya dan Tidak, maksud dari isian tersebut 
adalah pegawai yang diakui oleh UII sebagai pustakawan yang berpendidikan Diploma Tiga (D3) bidang IImu Perpustakaan dan D3 bidang lain ditambah sertifikat kompetensi dinyatakan 'Ya' sebagai Tenaga Teknis Perpustakaan dan dinyatakan 'Tidak' sebagai pustakawan. Dalam acuan yang terdapat pada SNP 010: 2011 maka mereka yang berijazah D3 tersebut merupakan tenaga tenaga teknis perpustakaan, bukan sebagai pejabat fungsional pustakawan.

Sementara itu ada sebanyak 14 orang $(32.56 \%)$ diangkat oleh UII sebagai pejabat fungsional pustakawan, akan tetapi apabila merunut pada SNI 7330: 2009 dan SNP 010: 2011, maka ke-14 orang tersebut tidak termasuk sebagai pejabat fungsional pustakawan maupun tenaga teknis perpustakaan. Ke 14 orang tersebut merupakan pejabat fungsional pustakawan UII yang berasal dari impasing pada tahun 1993 dan sampai sekarang mereka tetap berstatus pendidikan SLTA serta tidak melakukan penyesuaian dengan mengikuti pendidikan formal jenjang D3 atau S1. Hal ini telah diatur dalam Peraturan UII No. 15/PU/REK/ IX/2010 tentang Jabatan Fungsional, Pangkat dan Angka Kredit Pustakawan UII Bab IX Pasal 29 Ayat (1) angka 4 berbunyi: Bagi pegawai yang telah ditetapkan menjadi pustakawan dengan ijazah di bawah jenjang Diploma II, dan sudah menduduki jabatan pustakawan penyelia batas maksimum pangkat disetarakan dengan Diploma II sebagaimana tertuang dalam ayat (1) angka 1; dimana dalam ayat (1) angka 1 ini memberikan batas maksimum jabatan/pangkat/ golongan ruang yang dicapai adalah Pustakawan Penyelia, Pangkat Penata Tingkat I, Golongan/ Ruang III/d. Selanjutnya sebanyak 12 orang $(27.91 \%)$ berstatus sebagai tenaga administrasi, alias pejabat non pustakawan.

Dari uraian tersebut dapat diambil kesimpulan bahwa menurut SNP 010: 2011 tenaga perpustakaan UII berdasarkan kualifikasi pendidikan dan status jabatan menunjukkan bahwa :

a. Status Pustakawan: 6 orang (13.95\%)

b. Status Tenaga Teknis Perpustakaan merangkap Pustakawan : 11 orang (25.58\%) (berijazah D3/D2)

c. Status Tenaga Teknis Perpustakaan merangkap Pustakawan : 14 orang (32.58\%) (berijazah SLTA) d. Status Tenaga Administrasi Perpustakaan : 12 orang $(27.91 \%)$

Tenaga Teknis Perpustakaan dapat merangkap status sebagai pustakawan, hal ini telah diatur dalam UU No. 43 tahun 2007 Pasal 29 ayat (3).

\section{Rasio Pejabat Pustakawan dengan Tenaga Teknisi Perpustakaan dan Tenaga Administrasi}

Menurut SNI 7330: 2009 pada angka 8.2 memberikan penjelasan bahwa jumlah sumber daya manusia yang diperlukan dihitung berdasarkan perbandingan satu pustakawan, dua tenaga teknis perpustakaan dan satu tenaga administrasi.

Tabel 4 Rasio Pustakawan dengan Tenaga Teknisi Perpustakaan dan Tenaga Administrasi

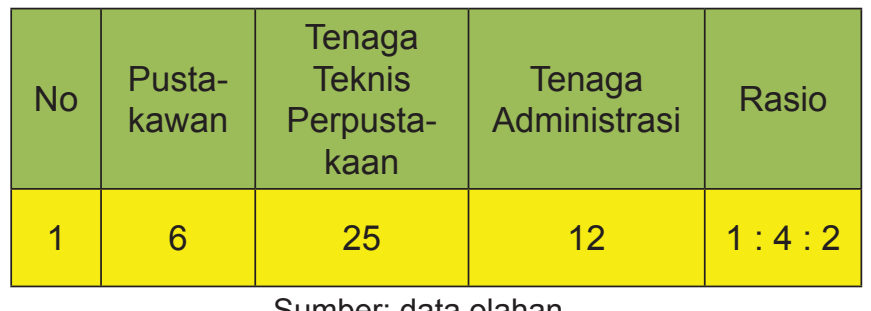

Sumber: data olahan

Tabel 4 terlihat, bahwa perbandingan pustakawan dengan tenaga teknis perpustakaan dan tenaga administrasi menunjukkan angka $1: 4$ : 2. Hal ini dapat diinterpretasikan bahwa tenaga perpustakaan UII masih didominasi tenaga teknis dan tenaga administrasi. Apabila mengacu kepada Standar yang ada, maka seharusnya UII memerlukan minimal 12 pustakawan, sehingga tingkat idealnya baru mencapai $50 \%$ saja.

\section{Rasio Jumlah Pustakawan dengan Jumlah Pemustaka}

Sebagaimana diatur dalam SNP 010: 2011 sudah dengan jelas disebutkan bahwa jumlah pustakawan yang diperlukan adalah 1 pustakawan berbading 500 pemustaka, dan hitungan lebih lanjut setiap 2000 mahasiswa ditambah satu pustakawan. Atau setara dengan 1:1250, artinya rasio kebutuhan pustakawan adalah 1 berdanding 1.250 pemustaka. 
Tabel 5 Rasio Jumlah Pustakawan dengan Jumlah Pemustaka

\begin{tabular}{|c|c|c|c|c|c|c|}
\hline $\begin{array}{c}\text { Nama } \\
\text { Lembaga }\end{array}$ & $\begin{array}{c}\text { Jumlah } \\
\text { Pustakawan } \\
\text { Murni }\end{array}$ & $\begin{array}{c}\text { Jumlah } \\
\text { Tenaga Teknis } \\
\text { Perpustakaan } \\
\text { Merangkap } \\
\text { Pustakawan }\end{array}$ & $\begin{array}{c}\text { Jumlah } \\
\text { Pustakawan } \\
\text { (Murni + } \\
\text { Tenaga } \\
\text { Teknis) }\end{array}$ & $\begin{array}{c}\text { Jumlah } \\
\text { Pemustaka } \\
\text { (Dosen, } \\
\text { karyawan, } \\
\text { dan } \\
\text { Mahasiswa }\end{array}$ & $\begin{array}{c}\text { Rasio } \\
\text { Pustakawan } \\
\text { Murni }\end{array}$ & $\begin{array}{c}\text { Rasio } \\
\text { Pustakawan } \\
\text { Rangkap }\end{array}$ \\
\hline UII & 6 & 25 & 31 & 17.000 & $1: 2.833$ & $1: 548$ \\
\hline $\begin{array}{c}\text { Standar } \\
\text { Yang } \\
\text { Seharusnya }\end{array}$ & 13 & 26 & - & - & $1: 1.250$ & - \\
\hline
\end{tabular}

Tabel 5 terlihat bahwa rasio Jumlah Pustakawan UII dengan Jumlah Pemustaka di Perpustakaan UII menunjukkan angka 1:548, hal ini menunjukkan bahwa tingkat rasio pustakawan UII telah mencapai angka 228\% dari SNP 010: 2011. Akan tetapi apabila dihitung rasio perbandingan antara pustakawan UII secara murni dapat ditemukan angka sebesar $1: 2.833$. Hal ini masih sangat jauh dari standar yang dibutuhkan, yaitu terletak pada angka $44 \%$ saja. Perpustakaan UII dengan jumlah pemustaka sebesar 17.000 , idealnya mempunyai pustakawan murni sebanyak 13 orang.

\section{Kualifikasi Kepala Perpustakaan}

Sebagaimana diatur dalam ketentuan pada ketiga peraturan yaitu SNI 7330: 2009, SNP 010: 2011 dan UU No 43 tahun 2007 bahwa kepala perpustakaan perguruan tinggi haruslah seorang yang minimal berpendidikan magister (S2) di bidang ilmu perpustakaan dan informasi, serta memiliki sertifikat kompetensi perpustakaan yang dikeluarkan oleh lembaga sertifikasi terakreditasi, dalam hal ini Perpustakaan Nasional Republik Indonesia. Saat ini perpustakaan UII dipimpin oleh seorang berpendidikan Doktor (S3) bidang IImu Teknik, dan sejauh yang penulis ketahui belum memiliki sertifikat kompetensi di bidang perpustakaan. Dengan demikian kepala perpustakaan UII saat ini belum memenuhi standar sebagai mana yang ditetapkan dalam peraturan yang ada.

\section{Pembahasan}

I Putu Suhartika dalam tulisannya yang dimuat pada http://suhartika.blogspot. com/2009/03/pengembangan-sdmperpustakaan-perguruan.html menjelaskan bahwa sumber daya manusia perpustakaan terdiri dari pustakawan (ahli dan terampil), staf administrasi dan tenaga $\mathrm{TI}$ atau staf lain yang berminat di bidang perpustakaan. Di dalam pengembangan pustakawan ke depan diharapkan dapat menjadikan pustakawan itu tidak hanya sebagai pustakawan biasa saja namun mempunyai fungsi sebagai information mediator, information expert, dan information manager (Klugkest, 2001: 9-11). Sebagai information mediator, pustakawan diharapkan sebagai penghubung antara peminta informasi (user) dengan sumber-sumber informasi, serta membantu pengguna dalam temu kembali informasi. Sebagai information expert, pustakawan diharapkan mampu berinteraksi dengan teknisi informasi seperti programmer dan web designer di dalam pengembangan informasi. Dia juga harus mengenal semua aspek-aspek informasi. Akhirnya, sebagai information manager, pustakawan harus mengenal berbagai macam pengelolaan bisnis yang berhubungan dengan perpustakaan.

Pustakawan ahli adalah pustakawan yang diangkat pertama kali memiliki latar belakang pendidikan S1 IImu Perpustakaan atau ilmu bidang lain yang telah disetarakan. Sementara pustakawan terampil adalah pustakawan yang diangkat pertama kali berlatarbelakang pendidikan minimal Diploma 2 IImu Perpustakaan atau ilmu bidang lain yang disetarakan. Dengan demikian pustakawan UII yang memiliki kategori sebagai pustakawan ahli adalah sebanyak 8 (enam) orang terdiri 4 orang berijazah S2 IImu Perpustakaan dan 4 orang berijazah S1 IImu Perpustakaan, dan selebihnya merupakan tenaga teknis perpustakaan (berijazah diploma dan SLTA ditambah kursus IImu Perpustakaan) sebanyak 23 orang. 
Tingkat Standarisasi Tenaga Perpustakaan ...(Sungadi)

\section{Isu-isu dalam pembinaan SDM perpustakaan yaitu: \\ - Perlunya pendidikan bagi teknisi perpustakaan (fungsional keterampilan/ asisten pustakawan), dan tenaga profesional perpustakaan (fungsional keahlian/ pustakawan),}

- Pengembangan profesi kepustakawanan deugan menghadiri seminar, diskusi ilmiah, lokakarya, membuat karya tulis, dan sejenisnya,

- Penguasaan teknologi informasi,

- Pergeseran nilai dan etos kerja yang disebabkan perubahan pola pikir

- Menyadarkan pustakawan akan pentingnya peranan dan fungsi di era informasi untuk mewujudkan tercapainya masyarakat informasi,

- Peralihan pengelolaan perpustakaan konvensional ke perpustakaan elektronik.

Dari uraian di atas dapat dikatakan bahwa pengembangan sumber daya manusia perpustakaan sangat perlu dilakukan dengan melakukan pola pembinaan SDM yang berkelanjutan mengenai pengetahuan dan keterampilan di bidang perpustakaan dan teknologi informasi.

Sesungguhnya dunia perpustakaan sangat erat dengan bidang lain seperti informasi dan komputer, sehingga seringkali kita mendengar kedua istilah itu digabung menjadi perpustakaan dan informasi. Untuk itu, maka para pustakawan sudah saatnya untuk mengetahui bidang-bidang lain tersebut selain bidang perpustakaan. Dengan melakukan hal itu diharapkan profesionalisme pustakawan menjadi lebih meningkat.

\section{Kompetensi Pustakawan}

Tujuan profesi kepustakawanan untuk menjadikan masyarakat informasi akan menjadi tercapai jika pustakawan yang merupakan pelaku (actor) utama profesi tersebut harus betul-betul mempunyai kompetensi di bidangnya. Kompetensi tersebut merupakan standarisasi atau tolak ukur untuk mengetahui kemampuan seseorang menggunakan pengetahuan dan keterampilan yang telah diperolehnya. Dengan adanya kompetensi tersebut diharapkan kehadiran pustakawan yang berkualitas akan menjadi kenyataan.
Sehubungan dengan perkembangan teknologi informasi di perpustakaan, maka kompetensi pustakawan dapat digolongkan menjadi kompetensi profesional dan kompetensi perorangan (Salmubi, 2006: 6). Kompetensi profesional pustakawan meliputi:

1. Pengetahuan mendalam akan isi sumbersumber informasi

2. Pengetahuan tentang subjek-subjek khusus yang relevan dengan kebutuhan client

3. Menggunakan TI yang tepat untuk mendapatkan, mengorganisasikan dan menyebarkan informasi

4. Mengembangkan layanan informasi secara berkesinambungan

5. Menyediakan instruksi perpustakaan yang excellent dan bermanfaat bagi pemakai

6. Mengembangkan layanan perpustakaan yang berkesinambungan.

Lebih lanjut, Salmubi merinci kompetensi pustakawan berbasis TI meliputi aspek-aspek sebagai berikut:

1. Memiliki komitmen untuk pelayanan excellent

2. Mencari dan menghadapi tantangan dan peluang baru

3. Mampu melihat perpustakaan dan layanannya secara komprehensif

4. Mampu membangun kemitraan dan kerjasama

5. Memiliki keterampilan berkomunikasi secara efektif

6. Memiliki kemampuan leadership

7. Memiliki kemampuan merencanakan program yang mengacu skala prioritas

8. Mampu membangun professional networking

9. Berpikir positif dan fleksibel terhadap segala perubahan yang terus berlangsung.

T.H.E. Journal (dalam Salmubi, 2006: 8) menyatakan bahwa pustakawan harus mempunyai sekurang-kurangnya 20 jenis skill teknologi informasi yaitu:

(1) Word processing skills; (2) Spreadsheet skills; (3) Database skills; (4) Electronic presentation skills; (5) Web navigation skills; (6) Websites design skills; (7) E-mail management skills; (8) Digital camera skills; (9) Computer network knowledge applicable to your local system; (10) File management \& windows explorer skills; (11) Downloading software from the web (knowledge including e-book); (12) Installing computer software onto a computer system; (13) 
WebCT or blackboard teaching skills; (14) Video conference skills; (15) Computer-related storage devices (disk, Cds, USB drives, zip disks, DVDs); (16) Scanner knowledge; (17). Knowledge of personal digital assistant (PDAs); (18) Deep web knowledge; (19) Education copyright knowledge; dan (20) Computer security knowledge.

Sementara itu menurut SulistyoBasuki dalam tulisannya yang dimuat dalam http://sulistyobasuki.wordpress. com/2013/10/27akreditasi-perpustakaanperguruan-tinggi/ Versi Perpusnas masih menerima pustakawan versi latihan yang berjumlah 50 jam latihan, padahal standar perpustakaan PT yang dirancang oleh Perpusnas justru tidak lagi menerima pustakawan versi pelatihan. SNI7330:2009 menyebutkan kepala perpustakaan PT berpendidikan minimal magister IImu Perpustakaan atau sarjana ditambah dengan pendidikan kesarjanaan IP. Di Universitas Indonesia, pendidikan semacam ini disebut jalur program ganda.

Keberadaan program pelatihan untuk menghasilkan pustakawan (fungsional) dengan jam terbatas sudah banyak dikritik, namun Perpusnas tetap tak bergeming, masih melanjutkan program itu padahal saat ini di Indonesia terdapat berbagai program pendidikan formal pustakawan dari Diploma 2 sampai dengan Magister (Sulistyo-Basuki 2013). Versi BAN menyebutkan secara jelas jumlah pustakawan yang berpendidikan S2 atau S3 disertai rumus :

Ad 2.1. Pustakawan dan kualifikasinya

Catatan: nilai dihitung dengan rumus berikut :

$$
A=\left(4 X_{1}+3 X_{2}+2 X_{3}\right) / 4
$$

$\mathrm{X}_{1}=$ jumlah pustakawan yang berpendidikan $\mathrm{S} 2$ atau S3.

$\mathrm{X}_{2}=$ jumlah pustakawan yang berpendidikan D4 atau S1.

$\mathrm{X}_{3}=$ jumlah pustakawan yang berpendidikan D1, D2, atau D3.

Maka versi Perpusnas sebaiknya menghilangkan pustakawan versi latihan yang bervariasi jumlahnya, mulai dari 2 minggu sampai dengan 628 jam atau kurang lebih empat bulan. Versi pelatihan ini mulai dikemukakan sekitar tahun 1980 an, sudah waktunya diubah karena saat ini di Indonesia terdapat S 2 lembaga pendidikan diploma 2, 25 lembaga pendidikan diploma 3, 15 program sarjana dan 5 program pascasarjana (Sulistyo-Basuki, 2013).
Dari uraian tersebut di atas, peneliti sejalan dengan pendapat Sulistyo-Basuki, bahwa untuk meningkatkan mutu pustakawan hendaknya keterampilan dan keahlian yang diperoleh dari diklat, kursus, dan sejenisnya sudah seharusnya mulai ditiadakan. Terkait dengan hal itu, maka pustakawan murni (berijazah S1 dan S2) UII yang saat ini baru ada 6 orang, perlu ditambah untuk mencapai ideal sesuai dengan SNP yaitu ditambah menjadi 13 orang. Sementara untuk tenaga teknisi Perpustakaan, UII saat ini dirasa sudah cukup sesuai dengan SNP, akan tetapi untuk 4 atau 5 tahun mendatang \pm 15 orang akan memasuki masa pensiun, sehingga sudah saatnya UII mulai sekarang dipandang perlu untuk melakukan antisipasi dengan jalan mulai mengangkat tenaga calon pustakawan baru. Apabila hal ini tidak segera diantisipasi, maka 4 tahun mendatang akan mengalami krisis pustakawan, karena pegawai baru yang diterima di perpustakaan harus bekerja minimal selama 2 tahun di perpustakaan untuk dapat diangkat sebagai pustakawan. Hal ini sebagaimana diatur dalam Peraturan Kepala Perpustakaan Nasional RI Nomor 2 tahun 2008 Bab IV halaman 71 dan Peraturan Universitas Nomor 15/PU/REK/2010 Pasal 4 yang menyebutkan bahwa pengangkatan pertama dalam jabatan pustakawan disyaratkan salah satunya adalah bertugas pada unit perpustakaan, dokumentasi, dan informasi sekurang-kurangnya selama 2 (dua) tahun berturut-turut.

\section{Kesimpulan}

Dari pembahasan tersebut, maka dapat disimpulkan bahwa:

1. Tingkat Pendidikan Tenaga Perpustakaan UII : S3 (1 orang $=2.33 \%$ ); S2 (3 orang = $6.98 \%$ ); S1 (3 orang $=6.98 \%$ ); D3 (11 orang $=25.58 \%$ ); D2 (3 orang $=6.98 \%$ ); SLTA $(20$ orang $=46.51 \%)$; dan SLTP $(2$ orang $=$ $4.65 \%)$.

2. Status Jabatan Tenaga Perpustakaan UII, menunjukkan:

a. Sebagai Pustakawan: 6 orang (13.95\%)

b. Sebagai Tenaga Teknis Perpustakaan merangkap Pustakawan: 11 orang (25.58\%) (berijazah D3/D2) 
Tingkat Standarisasi Tenaga Perpustakaan ...(Sungadi)
c. Sebagai Tenaga Teknis Perpustakaan merangkap Pustakawan : 14 orang (32.58\%) (berijazah SLTA)

\section{d. Sebagai Tenaga Administrasi Perpustakaan : 12 orang $(27.91 \%)$}

e. Tenaga Teknis Perpustakaan dapat merangkap status sebagai pustakawan, hal ini telah diatur dalam UU No. 43 tahun 2007 Pasal 29 ayat (3).

3. Perbandingan pustakawan dengan tenaga teknis perpustakaan dan tenaga administrasi menunjukkan angka 1:4:2. Hal ini dapat diinterpretasikan bahwa tenaga perpustakaan UII masih didominasi tenaga teknis dan tenaga administrasi. Apabila mengacu kepada Standar yang ada, maka seharusnya UII memerlukan minimal 12 pustakawan, dan hal ini menunjukkan bahwa tingkat idealnya baru mencapai $50 \%$ saja.

4. Rasio Jumlah Pustakawan UII dengan Jumlah Pemustaka di Perpustakaan UII menunjukkan angka 1:548, hal ini menunjukkan bahwatingkatrasio pustakawan UII telah mencapai angka $228 \%$ dari SNP 010: 2011. Akan tetapi apabila dihitung rasio perbandingan antara pustakawan UII secara murni dapat ditemukan angka sebesar 1:2.833. Hal ini masih sangat jauh dari standar yang dibutuhkan, yaitu terletak pada angka $44 \%$ saja. Perpustakaan UII dengan jumlah pemustaka sebesar 17.000 , idealnya mempunyai pustakawan murni sebanyak 13 orang.

\section{Saran}

Dari uraian tersebut, maka dapat diberikan saran sebagai berikut:

1. UII sudah saatnya menambah jumlah tenaga perpustakaan sehingga berstatus sebagai pejabat fungsional pustakawan sebesar minimal 7 orang, sehinggajumlahnya menjadi menjadi 13 orang pustakawan. Hal ini dapat dilakukan dengan cara menyekolahkan pustakawan yang berpendidikan D3 ke S1 IImu Perpustakaan, atau dengan mengangkat pegawai baru yang berpendidikan S1 IImu Perpustakaan dan Informasi, atau dengan cara kedua-duanya.

\section{Daftar Pustaka}

Bates, M. 1998. The newly minted MLS: what do we need to know today? Searcher 6(5), 30-33. Retrieved from CINAHL Plus with Full Text database.

Breeding, M. 2009. Social Networking Strategies for Professionals. Computers in Libraries, 29(9), 29-31. Retrieved from Library, Information Science \& Technology Abstracts database.

Farkas, Meredith. 1999. Librarian 2.0. Journal Information Science Vol. 22 No. 2

http://www.slideshare.net/librarianmer/librarian20-presentation. librarysuccess.org. diakses 6 Mei 2014.

Indonesia. 2007. Undang-undang Nomor 43 tahun 2007 tentang Perpustakaan

Mathews, J. and Pardue, H. 2009. The Presence of IT Skill Sets in Librarian Position Announcements. Coll Res Libr 70 No3 May 2009. The Princeton Review.

Perpustakaan Nasional RI, 2011. SNP 010:2011 Standar Nasional Perpustakaan Perguruan Tinggi. Jakarta : Perpustakaan Nasional RI.

Riduwan. 2003. Skala pengukuran variabelvariabel penelitian. Bandung: Alfabeta

Salmubi. 2006. Kompetensi Pustakawan Berbasis Teknologi Informasi. Makalah pada Pelatihan Manajemen Perpustakaan Digital di Makasar. Jakarta: Perpustakaan Nasional RI.

SNI 7330: 2009 Standar Nasional Indonesia Perpustakaan Perguruan Tinggi. Jakarta: Badan Standar Nasional.

Suhartika, I Putu. 2009. Peengembangan SDM Perpustakaan Perguruan Tinggi dalam http://suhartika.blogspot.com/2009/03/ pengembangan-sdm-perpustakaanperguruan.html. diakses 6 Mei 2014.

Sulistyo-Basuki. 2013. Standarisasi dan akreditasi bagi perpustakaan perguruan tinggi dalam konteks Indonesia. Seminar Nasional dan Workshop Standar Nasional dan Akreditasi Perpustakaan Perguruan Tinggi di Perpustakaan Universitas Sanata Dharma Yogyakarta tanggal 14 Maret 2013.

----------. 2013. Akreditasi Perpustakaan Perguruan Tinggi dalam http://sulistyobasuki. wordpress.com/2013/10/27akreditasiperpustakaan-perguruan-tinggi/ 
UNI ib

United States Department of Labour. http:// www.bls.gov/oco/ocos068.htm\#training diakses 7 Mei 2014.

Universitas Islam Indonesia. 2010. Peraturan UII Nomor 15/PU/REK/IX/2010 tentang Jabatan Fungsional, Pangkat dan Angka Kredit Pustakawan Universitas Isalam Indonesia. Yogyakarta: UII. 